\title{
Supplementing Rural Livelihoods through Backyard Duckery Farming in Murshidabad District of West Bengal, India
}

\author{
A. Roy $^{1}$, P.S. Roy ${ }^{1}$, S. Datta ${ }^{2 *}$, A. Haldar ${ }^{3}$, U. Roy ${ }^{1}$, P.K. Pathak ${ }^{1}$, \\ S. Patra ${ }^{1}$, A. Taleb ${ }^{1}$ and A. Maji ${ }^{1}$ \\ ${ }^{1}$ Krishi Vigyan Kendra, Milebasa, Murshidabad, West Bengal University of Animal and Fishery \\ Sciences, West Bengal, India \\ ${ }^{2}$ Department of Animal Genetics and Breeding, W. B. University of Animal and Fishery \\ Sciences, Kolkata-37, India \\ ${ }^{3}$ ICAR-Agricultural Technology Application Research Institute, Kolkata-97, India \\ *Corresponding author
}

A B S T R A C T

Keywords

Rural livelihoods, Backyard duckery, West Bengal.

Article Info

Accepted:

26 October 2017

Available Online:

10 December 2017
Sixty women farmers having early experience of backyard duckery farming from randomly selected 15 villages of Murshidabad district of West Bengal were selected for the present study to investigate the viability and economics of backyard duckery both with local ducks and Khaki Campbell ducks. The estimated cost of rearing was calculated by adding various costs i.e. cost of day old ducklings, feed, vaccine, medicine, labour and fixed expenditure i.e. cost of land, shed and equipments and the return was calculated by adding the incomes from the sale of eggs, drakes and spent ducks. From this research, it was found that the Khaki Campbell duck rearing is very profitable with an estimated benefit cost (B: C) ratio of 2.34 while for local ducks it was recorded as 1.84 .

\section{Introduction}

Duck rearing is a productive livestock business in the globe because of its egg, meat and feather. Like chicken, ducks are reared for eggs mainly and also for meat. Duck eggs are relatively larger, weighing about $4.5 \%$ of duck's body weight, compared to chicken, whose egg weight is only about $3.3 \%$ of the hen's body weight (Narhari, 2009). Moreover, ducks are more prolific than chicken and more adaptable to free-range system of rearing. They also grow faster than chicken.
Among the duck breeds Khaki Campbell is known to be the highest egg producer in the World. Nho et al., (1997) reported that Khaki Campbell ducks reared in Vietnam produced 271 eggs in herd system of management and 242 eggs in confined system of management. As per livestock census 2007, the duck population of India is 27.43 million constituting 8.52 percent of the total poultry population. As per FAO (2007) statistics, the duck meat production increased from 0.026 
million tonnes to 0.15 million tonnes, recording 577 percent increase in growth rate, in two decades. The leading states in duck population are West Bengal, Assam, Kerala, Andhra Pradesh, Tamil Nadu, UP, Bihar and Orissa (Narhari, 2009). Duck farming in India is characterized by nomadic, extensive, seasonal, and is still held in the hands of small and marginal farmers and nomadic tribes. Traditionally West Bengal and Kerala are the major consumer states for duck egg and meat and one of the reasons is that duck egg and meat highly suits and remains tastier for their fish based culinary preparations.

In West Bengal, desi ducks were being reared by women farmers for egg and meat purpose. They generally sold the male duck after maturation. On the basis of farmers feedback it was inferred that the income earned from desi duck farming is not sufficient for the women farmer to raise their livelihood status. Also, unexpected mortality in desi duck and poor productivity reduces their income level. In this situation Murshidabad Krishi Vigyan Kendra has conducted front line demonstrations on Khaki Campbell ducks under farmer's field condition in different blocks of Murshidabad district. However, till now no systemic studies have been conducted in respect to their productivity performance and benefit cost ratio in comparison to the desi duck reared by the rural women of this region. Keeping in view the present study has been undertaken to explore the economics of both improved breed of Khaki Campbell and desi duck in rural backyard system of rearing up to 18 months of age.

\section{Materials and Methods}

The study was conducted from May, 2016 to October, 2017 at 15 randomly selected villages of Murshidabad district of West Bengal, India, namely Balarampore, Bamunia, Beliapukur, Kusumkhola, Milebasa,
Kapasdanga, Kashiadanga, Kanapukur, Dakshin Basudevpur, Tentulia, Kolan, Radhakantapur, Tigarpara, Sonadanga and Ghugridanga covering 4 farmers from each village. Thus, a total of 60 farmers having experience of duck rearing near about two years and having minimum 15 numbers of desi ducks were selected for the study. However, while selecting the women farmers, preference was given to those women who were completed training on duck farming organized by any government organization. The existing 15 numbers of desi ducks and 15 numbers of Khaki Campbell ducks of either sex provided from State Poultry Farm, Kalyani, to each farmer were considered for the study. Day old Khaki Campbell and desi ducklings were kept in brooding up to 6 weeks of age and simultaneously vaccinated against Duck plague and Duck Cholera disease as per standard vaccination protocol. During brooding period, Khaki Campbell ducklings were provided with standard starter ration. After brooding, chicks were let loose at backyard environment after proper acclimatization. The primary data were collected for day old to 18 months of age of the ducks. The estimated cost of rearing was calculated by adding the variable cost i.e. cost of day old ducklings, feed cost, vaccine cost, medicine cost, labour cost and fixed cost i.e. land, duck shed and equipment cost. The return was calculated by adding the incomes from the sale of eggs, sale of drake and spent ducks. The data generated were tabulated and subjected to statistical analysis as per the method of Snedecor and Cochran (1994).

\section{Profitability analysis}

Gross margin analysis was used to determine the cost and returns from backyard duck production and then the Net Farm Income (NFI) of the duck farmers were estimated as per the method described by Oladunni and Fatuase (2014). The Gross Margin (GM) and 
Net Farm Income (NFI) were estimated with the help of following equations:

Equation 1: GM = TVP - TVC

Equation 2: $\mathrm{NFI}=\mathrm{GM}-\mathrm{TFC}$

Where, TVP $=$ Total value of production, $\mathrm{TVC}=$ Total variable cost, $\mathrm{TFC}=$ Total fixed cost

If $\mathrm{GM}>0$, then backyard poultry enterprise is considered profitable.

Finally, benefit cost ratio (BCR) was calculated by dividing the total net return by net cost of production.

\section{Results and Discussion}

Performance of Khaki Campbell and desi ducks under backyard system of rearing are presented in Table 1. At 8 weeks of age, the drake attained $380 \mathrm{~g}$ and duck $288 \mathrm{~g}$ weight and within 6-7 weeks of age it is ready to swim in pond (Fig. 1). The mortality after 21 weeks of age was recorded as $15 \%$ in Khaki Campbell duck and in desi duck it was recorded as $9 \%$. The average age at first egg of Campbell was found to be 172 days with a 193 numbers of average annual egg productions, while in case of desi duck the average age at first egg was recorded as 196 days with an average annual production of 79 numbers of eggs.

Early sexual maturity in Khaki Campbell duck may be attributed to the inherent potentialities of the breed which agreed with the results of Huque and Haque (1991). Like the age at first egg, Khaki Campbell ducks possessed the inherent capability of producing more eggs compared to desi due to the better genetic makeup of Khaki Campbell duck. The data indicates that the desi ducks to be more resistant to disease and parasites and can be adapted to adverse condition than those of Campbell ducks. The results on mortality in different age groups agreed with the results of Hamid et al., (1988) where they found lower mortality in desi ducks. The estimated cost of rearing of 15 desi and 15 Khaki Campbell ducks under backyard system of rearing for 18 months of age are presented in Table 2 . During the study it was found that for Khaki Campbell, the cost of labour accounted the highest percentage $(70.64 \%)$ of rearing cost followed by cost of feed $(11.30 \%)$, depreciation cost on shed $(10.46 \%)$, cost of ducklings $(6.59 \%)$ and cost of medicine, feed supplement $(1.00 \%)$. Similarly, in case of desi duck the expanses for the labour is also highest $(79.13 \%)$ among the other expanses of rearing, which is also higher than that of labour expanses of Khaki Campbell ducks rearing. The expanses for the duck shed depreciation cost, cost of ducklings, cost of feed, cost of medicine and feed supplement accounted 11.72, 5.63, 2.81 and $0.07 \%$ respectively. Uddin et al., (2013) reported that labour cost estimated to be the highest in backyard poultry rearing. The study also shows same results in case of duck farming. Present finding is contradictory with the finding of Jha and Chakrabarti (2017), where study revealed that feed cost constituted the highest expenditure for Khaki Campbell ducks under backyard rearing condition.

The expanses of medicine and feed supplement for desi duck is lower than Khaki Campbell duck because desi ducks have better adaptability than that of Khaki Campbell ducks in the backyard condition. The present findings on better adaptability of desi duck than Campbell is comparable to the reports of Islam et al., 2016 obtained in poultry. In the present study, the total production cost for Khaki Campbell ducks was found to be higher (Rs. 4777.95) than that of the production cost for desi ducks (Rs.4264.95) which might be due to the higher duckling and feed cost of Campbell ducks. 
Table.1 Performance of Khaki Campbell and Desi duck under backyard system of rearing

\section{Performance}

\begin{tabular}{|c|c|c|c|c|c|}
\hline \multirow{2}{*}{ S. No. } & \multirow[t]{2}{*}{ Trait } & \multicolumn{2}{|c|}{ Khaki Campbell } & \multicolumn{2}{|c|}{ Desi } \\
\hline & & Male & Female & Male & Female \\
\hline \multirow[t]{4}{*}{1} & Body wt. (g) & & & & \\
\hline & Day old chicks & 36 & 31 & 28 & 25 \\
\hline & 8 week & 380 & 288 & 330 & 242 \\
\hline & 20 week & 1209 & 1176 & 1122 & 989 \\
\hline 2 & Age at first egg (days) & - & 172 & - & 196 \\
\hline 3 & Mortality up to 10 weeks & $6 \%$ & $6 \%$ & $4 \%$ & $4 \%$ \\
\hline 4 & Mortality up to 20 weeks & $12 \%$ & $12 \%$ & $7 \%$ & $7 \%$ \\
\hline 5 & Mortality after 21 weeks (Laying stage) & $15 \%$ & $15 \%$ & $9 \%$ & $9 \%$ \\
\hline 6 & Average annual egg production & - & 193 & - & 79 \\
\hline 7 & Egg Colour & & Light brown & & Light brown \\
\hline
\end{tabular}

Table.2 Estimated rearing cost of 15 Khaki Campbell and 15 Desi Ducks under backyard system

\begin{tabular}{|c|c|c|c|}
\hline \multirow[b]{2}{*}{ S. No. } & \multirow[b]{2}{*}{ Particulars } & \multicolumn{2}{|c|}{ Cost of Rearing (Rs.) } \\
\hline & & $\begin{array}{c}\text { Khaki } \\
\text { Campbell }\end{array}$ & Desi \\
\hline 1 & Variable cost & & \\
\hline a. & $\begin{array}{l}\text { Cost of a day old ducklings @ Rs. 21/- for Khaki Campbell and @ Rs. } \\
\text { 16/- for desi chicken }\end{array}$ & $\begin{array}{c}315.00 \\
(6.59)\end{array}$ & $\begin{array}{c}240.00 \\
(5.63)\end{array}$ \\
\hline b. & Cost of feed up to 42 days of age & & \\
\hline 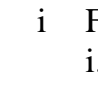 & $\begin{array}{l}\text { For Khaki Campbell ducklings } 1.2 \mathrm{~kg} \text { of standard starter ration/duckling } \\
\text { i.e. } 18 \mathrm{~kg} @ 30 / \text { - per kg }\end{array}$ & $\begin{array}{l}540.00 \\
(11.30)\end{array}$ & - \\
\hline ii $\quad \mathrm{F}$ & $\begin{array}{l}\text { For desi ducklings } 8 \mathrm{~kg} \text { of broken rice, rice bran \& wheat flour @ Rs. } \\
\text { 15/- per kg for } 15 \text { nos. ducklings }\end{array}$ & - & $\begin{array}{l}120.00 \\
(2.81)\end{array}$ \\
\hline c $\mathrm{C}$ & Cost of vaccine (Govt. Supply in free of cost) & - & - \\
\hline d $\quad \mathrm{F}$ & $\begin{array}{l}\text { For Khaki Campbell ducklings cost of medicine, feed supplement @ Rs. } \\
\text { 3.20/- ducklings }\end{array}$ & $\begin{array}{l}48.00 \\
(1.00)\end{array}$ & - \\
\hline e $\mathrm{F}$ & $\begin{array}{l}\text { For desi ducklings cost of medicine, feed supplement @ Rs. 2.00/- } \\
\text { ducklings }\end{array}$ & - & $\begin{array}{l}30.00 \\
(0.07)\end{array}$ \\
\hline $\mathrm{f} \quad \mathrm{F}$ & $\begin{array}{l}\text { For both the flock (Campbell and desi) cost of labour @ } 20 \mathrm{hrs} . / \text { month } \\
=2.5 \text { Man-days x } 18 \text { months = } 45 \text { man-days x Rs. } 150 / \text { - per Man-day = } \\
\text { Rs. } 6750.00\end{array}$ & $\begin{array}{l}3375.00 \\
(70.64)\end{array}$ & $\begin{array}{c}3375.00 \\
(79.13)\end{array}$ \\
\hline & Total Variable cost & 4278.00 & 3765.00 \\
\hline $2 I$ & Fixed cost & & \\
\hline a I & Land & $\begin{array}{l}\text { Available with } \\
\text { the farmers }\end{array}$ & $\begin{array}{l}\text { Available with } \\
\text { the farmers }\end{array}$ \\
\hline b $\quad$ I & $\begin{array}{l}\text { Low cost duck shed made with locally available material } \\
\text { (L/S) }\end{array}$ & 1000.00 & 1000.00 \\
\hline c I & Depreciation cost on duck shed @ $33.33 \%$ per year & $\begin{array}{l}499.95 \\
(10.46)\end{array}$ & $\begin{array}{l}499.95 \\
(11.72)\end{array}$ \\
\hline d $\quad$ L & Drinker/ Feeder & Locally made & Locally made \\
\hline & Total fixed cost & 499.95 & 499.95 \\
\hline 37 & Total cost/value of production $(1+2)$ & 4777.95 & 4264.95 \\
\hline $4 c$ & Cost of production per bird (D/15) & 318.53 & 284.33 \\
\hline
\end{tabular}


Table.3 Estimated return from Khaki Campbell and Desi ducks

\begin{tabular}{|c|c|c|c|c|c|}
\hline S. No. & Particulars & $\begin{array}{c}\text { Khaki Campbell } \\
(n=15)\end{array}$ & $\begin{array}{c}\text { Amount } \\
\text { (Rs.) }\end{array}$ & $\begin{array}{c}\text { Desi } \\
(n=15)\end{array}$ & $\begin{array}{c}\text { Amount } \\
\text { (Rs.) }\end{array}$ \\
\hline 1 & $\begin{array}{l}\text { Income from sale of } \\
\text { eggs (from } 7 \text { nos. of } \\
\text { Campbell \& } 8 \text { nos. of } \\
\text { Desi ducks) }\end{array}$ & $\begin{array}{l}\text { Avg. annual egg } \\
\text { production } 170 \\
\text { eggs/duck i.e. } 1190 \text { nos. } \\
\text { of eggs @ 8/egg }\end{array}$ & $\begin{array}{l}9520.00 \\
(85.07)\end{array}$ & $\begin{array}{l}\text { Avg. annual egg } \\
\text { production } 73 \\
\text { eggs/duck i.e. } 584 \text { nos. } \\
\text { of eggs @ 10/egg }\end{array}$ & $\begin{array}{l}5840.00 \\
(74.46)\end{array}$ \\
\hline 2 & $\begin{array}{l}\text { Sale of drakes ( } 6 \text { nos. } \\
\text { of Campbell \& } 6 \text { nos. } \\
\text { of Desi) }\end{array}$ & $\begin{array}{l}\text { Avg. weight: } 1.47 \mathrm{~kg} \text {. } \\
\text { Total weight: } 8.82 \mathrm{~kg} @ \\
\text { Rs. } 110 / \mathrm{kg}\end{array}$ & $\begin{array}{l}970.20 \\
(8.67)\end{array}$ & $\begin{array}{l}\text { Avg. weight: } 1.29 \mathrm{~kg} \text {. } \\
\text { Total weight: } 7.74 \mathrm{~kg} \\
\text { @ Rs. } 140 / \mathrm{kg}\end{array}$ & $\begin{array}{l}1083.60 \\
(13.82)\end{array}$ \\
\hline 3 & $\begin{array}{l}\text { Sale of spent ducks ( } 7 \\
\text { nos. of Campbell \& } 8 \\
\text { nos. of Desi) }\end{array}$ & Rs. $100 /$ duck & $\begin{array}{l}700.00 \\
(6.26)\end{array}$ & Rs. $115 /$ duck & $\begin{array}{l}920.00 \\
(11.73)\end{array}$ \\
\hline 4 & Total gross income & - & 11190.20 & - & 7843.60 \\
\hline 5 & Net income & - & 8787.25 & - & 6343.65 \\
\hline 6 & Net income/duck & - & 585.82 & - & 422.91 \\
\hline 7 & $\begin{array}{l}\text { Gross margin } \\
\text { (Net income-Total } \\
\text { variable cost) }\end{array}$ & - & 4509.25 & - & 2578.65 \\
\hline 8 & $\begin{array}{l}\text { Net farm income } \\
\text { (GM-total fixed cost) }\end{array}$ & - & 4009.30 & - & 2078.70 \\
\hline 9 & $\begin{array}{l}\text { Benefit-Cost-ratio } \\
\text { (BCR) }\end{array}$ & - & 2.34 & - & 1.84 \\
\hline
\end{tabular}

Fig.1 Comparison of body weight (gm) of Khaki Campbell and Desi duck

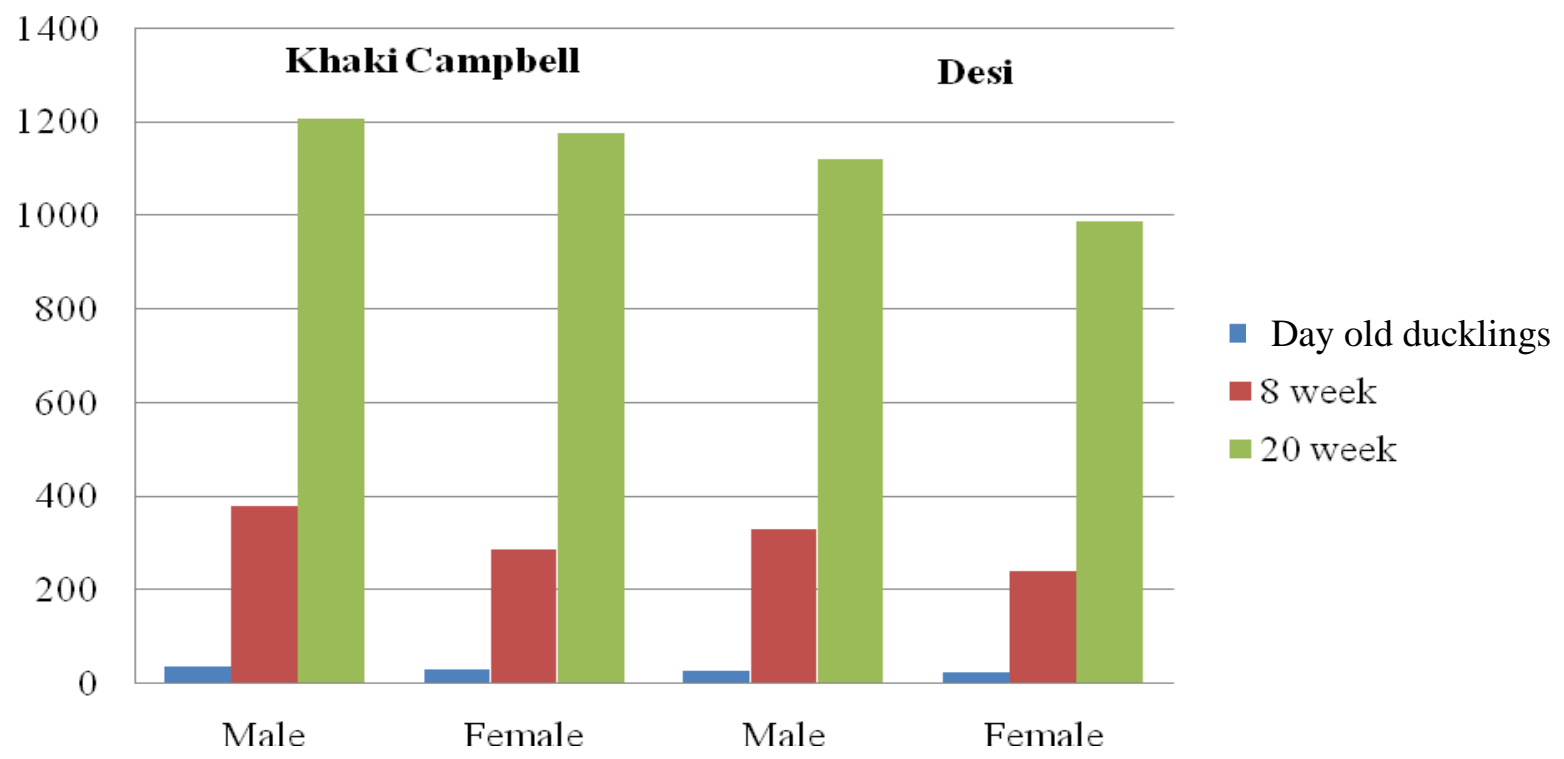

From the study it was found that maximum amount of return in case of Khaki Campbell ducks was obtained from selling of eggs (85.07\%), followed by sale of drakes $(8.67 \%)$ and sale of spent ducks $(6.26 \%)$. This return trend i.e. highest income from the selling of eggs $(74.46 \%)$, followed by sale of drakes $(13.82 \%)$ and sale of spent ducks $(11.73 \%)$ was also observed in case of desi ducks (Table 3). The total gross income and net 
income from the Khaki Campbell ducks was recorded as Rs. 11190.20 and Rs. 8787.25 respectively, which is $57.15 \%$ and $46.78 \%$ higher than that of gross income (Rs. 7843.60) and net income (Rs. 6343.65) from the desi ducks.

The Gross Margin and the Net Farm Income from the backyard Khaki Campbell and desi ducks rearing was recorded as Rs. 4509.25, Rs. 2578.65, Rs. 4009.30 and Rs. 2078.70, respectively which indicate that the backyard Khaki Campbell duck rearing is very much profitable. The estimated benefit cost (B: C) ratio for Khaki Campbell and desi ducks were recorded as 2.34 and 1.84 which indicated that rearing of Khaki Campbell was much more profitable than that of rearing of desi duck. Higher B: C ratio in Khaki Campbell duck than that of desi duck might be due to better genetic makeup of Khaki Campbell for higher egg in the given period. Similar effect was shown by Uddin et al., 2013 in case of poultry.

The farmers made a profitable use of improved breed of Khaki Campbell. Ducks supplement their feed by foraging; hence it will reduce the feed cost.

Therefore, focus should be on intervention of Khaki Campbell, which thrived well in rural backyard condition and will enhance the income to farmer livelihoods and in turn reducing poverty and increasing food security. Duck farming in India is in an emerging sector. Thus the women farmer must be given training on duck farming to equip them with relevant skills to merge scientific methods for improving their productivity.

\section{Acknowledgement}

The authors are highly thankful to the farmers of 15 villages who involved in participatory mode of research in backyard duck farming and provided the requisite and comprehensive information.

\section{References}

FAO. 2007. The state of the world's animal genetic resources for food and agriculture. FAO, Rome.

Hamid, M. A., S. M. R. K. Chowdhary and S. D. Choudhury. 1988. A comparative study on the performances of growing ducklings Khaki Campbell, Indian Runner and Indigenous ducks under farm conditions. Indian journal of Poultry Science. 23(2): 118-21.

Huque, Q. M. E. and M. E. Haque. 1991. A study on the efficiency of desi (local), khaki Campbell and Jinding duck in an integrated duck-cum-fish farming. Progress report. Poultry production research division. Bangladesh Livestock Research Institute, Savar, dacha, Bangladesh.

Islam, Md. Asadul., Md. Abdur Rahman Howlider, Md. Ashadul Alam, Md Abu Heyamet and Manika Debnath. 2016. Present status, problem and prospect of duck farming in rural areas of Mymensingh district, Bangladesh. Asian J. Med. Biol. Res. 2(2): 202212.

Jha, B. K. and A. Chakrabarti. 2017. Duck Farming: A Potential Source of Livelihood in Tribal Village. Journal of Animal Health and Production. 5(2): 39-43.

Narhari, D. 2009. Housing and management of ducks. IV World Waterfowl Conference, Thrissur, India. 45-47.

Nho, L.T. and Tieu H.V. 1997. Egg production and economic efficiency of Khaki Campbell ducks reared on locally available feedstuffs in the coastal land stretch of the Red River Delta. Livest Res Rural Dev. 9(1). 
Oladunni, M. E. and A. I. Fatuase. 2014. Economic analysis of backyard poultry farming in Akoko North West Local Government area of Ondo State, Nageria. Global Journal of Biology, Agriculture and Health Sciences. 3(1): 141-147.

Snedecor, G. W. and W. G. Cochran. 1994.

Statistical Methods, 6th edition,
(Oxford and IBH Publishing Co., Calcutta, India.

Uddin, M. T., M. M. Islam, S. Salam and S. Yasmin. 2013. Economics of native poultry rearing in the coastal regions of Bangladesh. Bangladesh Journal of Animal Science. 42(1): 49-56.

\section{How to cite this article:}

Roy, A., P.S. Roy, S. Datta, A. Haldar, U. Roy, P.K. Pathak, S. Patra, A. Taleb and Maji, A. 2017. Supplementing Rural Livelihoods through Backyard Duckery Farming in Murshidabad District of West Bengal, India. Int.J.Curr.Microbiol.App.Sci. 6(12): 3460-3466. doi: https://doi.org/10.20546/ijcmas.2017.612.402 